Website: http://journal.umy.ac.id/index.php/mrs

DOI: $10.18196 / \mathrm{jmmr} .5118$.

\title{
Pengaruh Gaya Kepemimpinan dan Loyalitas Karyawan Terhadap Kinerja Karyawan di Rumah Sakit Islam Hidayatullah Yogyakarta
}

\section{Rita Ivana Ariyani*}

*Penulis Korespondensi: rita.ivana78@gmail.com

${ }^{1}$ Rumah Sakit Islam Hidayatullah Yogyakarta

${ }^{2}$ Magister Manajemen Rumah Sakit Universitas Muhammadiyah Yogyakarta

\begin{tabular}{lr}
\hline INDEXIN G & \\
\hline Keywords: & \\
Leadership & style, \\
employee's & loyalty, \\
employee's performance
\end{tabular}

\begin{tabular}{l} 
A B S T R A C T \\
\hline The background of this research is Hidayatullah Islamic Hospital (RSI) Yogyakarta and is done \\
through leadership interferential, employee's loyalty gives influence toward employee's performance. \\
(1) The phenomenon factor of harmonious relationship between leader and subordinate. (2) Factor of \\
employee's performance which has not yet indicating employment conduciveness. (3) Factor of \\
employee's loyalty toward the lack of leader's concern on employee's performance and opportunity \\
to receive compensation. (4) The phenomenon of employee's performance; the employee's \\
incompetence in comprehending leader's instruction and the individual employee's minimum \\
responsibility which hinder the work performance. Data were compiled through interview and \\
questionnaire, and were classified into primary and secondary data. The sample of the research \\
consisted of 40 respondents. Method used in analyzing the data was linearity test, significance test of \\
multiple linear regression coefficient, t test, F test, R2. The conclusions of the research are; (1) There \\
is a positive and significant influence of leadership style toward the employee's performance at \\
Hidayatullah islamic hospital Yogyakarta. (2) There is a positive and significant influence of \\
employee's loyalty toward employee's performance at Hidayatullah islamic hospital Yogyakarta. (3) \\
The independent variable (leadership style and employee's loyalty) gives positive and significant \\
influence toward the employee's performance at Hidayatullah Islamic hospital Yogyakarta
\end{tabular}

(C) 2016 JMMR. All rights reserved

Article history: received 12 April 2016; revised 22 Mei 2016; accepted 17 Juni 2016

\section{PENDAHULUAN}

Pelayanan yang baik terhadap pelanggan tetap menjadi tujuan utama rumah sakit agar pelanggan tidak melakukan penilaian buruk terhadap kinerja rumah sakit sebagai pelayanan kesehatan (Darwito, 2008). Rumah sakit sebagai organisasi pelayanan kesehatan terdiri dari bagian-bagian yang saling tergantung satu sama lain. Setiap organisasi memerlukan koordinasi dan komunikasi supaya masing-masing bagian dari organisasi bekerja sesuai dengan tanggungjawab. Tanpa koordinasi sulit bagi rumah sakit untuk berfungsi dengan baik. Koordinasi dapat dilakukan dengan menjalin komunikasi antara karyawan dengan karyawan, maupun pimpinan dengan karyawannya (Wright, 1997).

Kepemimpinan yang efektif, dapat memberikan pengarahan terhadap usaha-usaha setiap karyawan dalam mencapai tujuan organisasi, dan dalam mengatur bawahannya seorang pemimpin harus mampu membaca situasi yang tepat, sehingga dapat memberikan pandangan dalam menghadapi dan menyelesaikan masalah (Hardani, 2013).

Kepemimpinan yang baik dibutuhkan untuk mengembangkan karyawan dan membangun loyalitas karyawan demi meningkatkan produktivitas.

Fenomena yang ditemukan peneliti pada pra penelitian menunjukkan bahwa secara interferensial gaya kepemimpinan dan loyalitas karyawan mempunyai pengaruh terhadap kinerja karyawan di Rumah Sakit Islam HidayatullahYogyakarta.

Dari data yang diperoleh di Rumah Sakit Islam Hidayatullah Yogyakarta didapatkan indikasi bahwa pada tahun 2011 tingkat turn overkaryawan di Rumah Sakit Islam Hidayatullah Yogyakarta cukup tinggi dan pada tahun 2011 pula terdapat penurunan data BOR, LOS dan BTO. Fenomena ini menjadi tanda tanya bagi peneliti apakah ada pengaruh antara gaya 
kepemimpinan dan loyalitas karyawan terhadap kinerja karyawan karena pada akhir tahun 2011 terjadi perubahan jajaran manajemen di Rumah Sakit Islam Hidayatullah Yogyakarta.

Masalah yang akan dirumuskan oleh peneliti adalah : (1) Apakah gaya kepemimpinan berpengaruh terhadap kinerja karyawan? (2) Apakah loyalitas berpengaruh terhadap kinerja karyawan? (3) Apakah gaya kepemimpinan dan loyalitas karyawan secara bersama-sama berpengaruh terhadap kinerja karyawan

\section{METODE PENELITIAN}

Penelitian ini dirancang sebagai penelitian survey yang bersifat menjelaskan fenomena (explanatory research). Ditinjau dari tujuannya, penelitian ini termasuk penelitian korelasional (Razabieh dkk, 2002) yang menyatakan bahwa penelitian korelasional bertujuan menetapkan besarnya hubungan/pengaruh antara variabel.
Jenis penelitian ini adalah kuantitatif dengan rancangan penelitian cross sectional survey. Rancangan cross sectional survey adalah jenis penelitian yang menekankan untuk pengukuran atau observasi data variable independent dan dependent hanya satu kali pada suatu saat tertentu (Nursalam, 2009).Ada dua jenis variabel dalam penelitian ini, yakni variabel dependen, yaitu kinerja karyawandan variabel independen yakni gaya kepemimpinan dan loyalitas karyawan. Subyek penelitian ini adalah karyawan Rumah Sakit Islam Hidayatullah Yogyakarta. Obyek Penelitian ini dilakukan di Rumah Sakit Islam Hidayatullah Yogyakarta. Penelitian ini berlangsung selama 3 bulan yakni pada bulan Januari 2014 sampai dengan bulan April 2014. Populasi dalam penelitian ini adalah seluruh karyawan yang bekerja di Rumah Sakit Islam Hidayatullah Yogyakarta yang berjumlah 224 karyawan dengan rincian sebagai berikut

Tabel 1. GAMBARAN KETENAGAAN RSIH TAHUN 2014

\begin{tabular}{clccccc}
\hline & & Jumlah Sdm & \multicolumn{3}{c}{ Status Ketenagakerjaan } \\
No & \multicolumn{1}{c}{ Jenis Tenagakerja } & Yang Ada & Tetap & Kt* $^{*}$ & Tamu & Ojt $^{*}$ \\
\hline 1 & Tenaga Medis & 30 & 6 & 5 & 19 & 2 \\
2 & Paramedis & 89 & 72 & 15 & & 4 \\
3 & Tenaga Kesehatan. Lain & 73 & 29 & 26 & 4 & 4 \\
4 & Non Medis Lain & 42 & 33 & 5 & & 10 \\
5 & Jumlah & 224 & 140 & 51 & 23 & \\
\hline
\end{tabular}

Sumber : Rumah Sakit Islam Hidayatullah Yogyakarta

*):KT adalah pegawai kontrak, OJT adalah pegawai On Job Training

Besarnya sampel yang digunakan adalah jumlah seluruh populasi yang memenuhi kriteria inklusi yakni karyawan yang berstatus pegawai perusahaan, pendidikan minimal SLTA dengan masa kerja $>2$ tahun dan bersedia berperan dalam penelitian, dan mengeluarkan subyek yang memenuhi kriteria eklusi yakni karyawan yang sedang cuti dan karyawan yang sedang mengikuti tugas belajar, sehingga besarnya sampel sejumlah 140 orang responden. Pengambilan sampel penelitian ini menggunakan teknik proportionale simple random samplingdan mengkombinasikan dengan teknik purposive sampling. Penelitian ini menggunakan teknik kuesioner sebagai sumber data primer dan teknik studi dokumentasi sebagai sumber data sekunder.

\section{Gaya Kepemimpinan}

Pengukuran variabel gaya kepemimpinan dengan menggunakan kuesioner Leader Behavior Analysis(LBA) by others yang telah dikembangkan oleh Balanchard Training Development. Data diukur dengan skala nominal. Jumlah pilihan terbanyak yang diperoleh menunjukkan gaya kepemimpinan yang diterapkan pimpinan berdasarkan persepsi karyawan. Kuesioner gaya kepemimpinan terdiri dari 12 butir pertanyaan dan setiap butirnya merupakan kejadiankejadian sehari-hari di tempat kerja, meliputi kegiatan yang paling sederhana hingga paling kompleks. Setiap butir pertanyaan disediakan empat jawaban yang masing-masing menggambarkan gaya kepemimpinan direktif, suportif, delegatif dan partisipatif. 


\section{Loyalitas Karyawan}

Variabel loyalitas karyawan diukur dengan menggunakan instrument yang dikembangkan oleh Mowday dan Steers (1979) yang telah dimodifikasi.

\section{Kinerja Karyawan}

Indikator pengukur variabel kinerja karyawan menggunakan kuesioner yang mengacu pada penelitian Saputra (2010), dengan menggunakan indikator menurut untuk pekerjaanMathis dan Jackson (2006)

\section{Teknik Analisa Data}

\section{Uji Validitas dan Reliabilitas}

Pengukuran Validitas dan reliabilitas dengan melakukan perbandingan uji vaiditas dan reliabilitas terhadap responden yang berbeda. Pelaksanaan uji coba dilakukan kepada 30 karyawan di RS Pura Raharja Medika Kulon Progo (uji coba dilakukan di luar objek penelitian/ RS Islam Hidayatullah Yogyakarta).

\section{Uji Prasarat Analisis}

Uji prasarat análisis menggunakan uji asumsi klasik terdiri dari ; Uji Normalitas, Uji Linieritas, Uji Heterokedastisitas, Uji Linieritas dan Uji Multikolinieritas. Dalam penelitian ini hanya digunakan Uji Normalitas karena telah cukup memadai untuk mengetahui pengaruh yang linier terhadap variabel yang diukur. Uji Normalitas dilakukan untuk menguji linieritas antara variable bebas gaya kepemimpinan (X1), loyalitas karyawan (X2) dan satu variable terikat kinerja karyawan rumah sakit Islam Hidayatullah Yogyakarta (Y) dengan menggunakan bantuan komputer program SPSS versi 17 for Windows 2013.

\section{Analisis Data}

Alat analisis ini mempunyai tiga ukuran dasar, yaitu :

\section{Regresi Linier Berganda}

Analisis garis regresi dapat dibuat suatu persamaan garis berdasarkan rumus matematik yang menunjukkan pengaruh antara variabel yang diketahui dengan variabel yang tidak diketahui meliputi : gaya kepemimpinan (X1), loyalitas karyawan (X2). Variabel dependen kinerja karyawan rumah sakit Islam Hidayatullah Yogyakarta (Y).

\section{Uji t}

Uji $\mathrm{t}$ digunakan untuk menguji keberartian koefisien regresi secara parsial, menggunakan rumus hipotesis sebagai berikut :

$$
\mathrm{t}=\frac{\beta_{\mathrm{i}}-\beta_{\mathrm{i}}}{\mathrm{se}-\left(\bar{\beta}_{\mathrm{i}}\right)}
$$

Dimana :

$$
\begin{aligned}
& \beta_{\mathrm{i}}=\text { Koefisien regresi } \\
& \text { Se }=\text { Standart error of estimatie } \\
& \beta_{\mathrm{i}}=\text { Distribusi variabel normal }
\end{aligned}
$$

Penggunaan lambang denganderajat kebebasan $\mathrm{N}-\mathrm{k}$, dimana $\bar{\beta}_{\mathrm{i}}$ adalah elemen manapun dari $\beta$. Oleh karena itu distribusi $\mathrm{t}$ dapat digunakan untuk menguji hipotesis.

\section{Uji F}

Uji F yaitu untuk menguji keberartian koefisien regresi secara keseluruhan, dengan rumus hipotesis sebagai berikut:

$$
\text { F Hitung }=\frac{\mathrm{R}^{2} /(\mathrm{k}-1)}{\left(1-\mathrm{R}^{2}\right) /(\mathrm{n}-\mathrm{k})}
$$

Dimana :

$$
\begin{aligned}
& \mathrm{R}^{2}=\text { Koefisien determinasi } \\
& \mathrm{k}=\text { Banyaknya variabel bebas } \\
& \mathrm{n}=\text { Banyaknya sampel }
\end{aligned}
$$

Pengujian melalui uji $\mathrm{F}$ atau variasinya adalah membandingkan $F$ hitung observasi $\left(F_{h}\right)$ dengan $F$ tabel $\left(\mathrm{F}_{\mathrm{t}}\right)$ pada $\mathrm{a}=0,05$.

\section{Koefisien Determinasi $\left(\mathbf{R}^{2}\right)$}

Selanjutnya untuk melihat kemampuan variabel bebas dalam menerangkan variabel tidak bebas dapat diketahui dari besarnya koefisien determinasi berganda $\left(\mathrm{R}^{2}\right)$. Jika $\mathrm{R}^{2}$ yang diperoleh dari hasil perhitungan semakin besar (mendekati satu), maka dapat dikatakan 
bahwa sumbangan dari variabel bebas terhadap variasi variabel tidak bebas semakin besar. Secara umum dikatakan bahwa besarnya koefisien determinasi berganda $\left(\mathrm{R}^{2}\right)$ berada antara 0 dan 1 atau $0 \leq$ $\mathrm{R}^{2} \leq 1$.

\section{HASIL DAN PEMBAHASAN}

\section{Hasil Uji Validitas dan Reliabilitas}

\section{Hasil Uji Validitas}

Hasil uji validitas angket mengenai Gaya kepemimpinan sebanyak 12 butir pernyataan dan terdapat 2 pernyataan yang tidak valid.Hasil uji validitas angket Loyalitas Karyawan sebanyak 15 butir pernyataan dan terdapat 3 pernyataan yang tidak valid. Hasil uji validitas angket kinerja karyawan sebanyak 19 butir pernyataan dan terdapat 5 pernyataan yang tidak valid.

\section{Hasil Uji Reliabilitas}

Hasil uji reliabilitas instrument mengenai hasil nilai untuk Gaya kepemimpinan $\left(\mathrm{X}_{1}\right)$ diperoleh sebesar 0,901, apabila dikonsultasikan dengan $r_{\text {tabel }}$ dengan taraf signifikansi 0,05 dan jumlah sampel sebanyak 30 maka diperoleh nilai $r_{\text {tabel }}$ 0,361. Sehingga 0,901 > 0,361 maka instrument variable gaya kepemimpinan $\left(\mathrm{X}_{1}\right)$ dinyatakan reliabel. Loyalitas karyawan $\left(\mathrm{X}_{2}\right)$ diperoleh nilai sebesar 0,941, apabila dikonsultasikan dengan $r_{\text {tabel }}$ dengan taraf signifikansi 0,05 dan jumlah sampel sebanyak 30 diperoleh nilai $r_{\text {tabel }} 0,361$. Sehingga $0,870>0,0,361$ maka instrument variabel $\mathrm{X}_{2}$ dinyatakan reliabel. Hasil nilai untuk Kinerja karyawan (Y) diperoleh nilai sebesar 0,939, apabila dikonsultasikan dengan $r_{\text {tabel }}$ dengan taraf signifikansi 0,05 dan jumlah sampel sebanyak 30 maka diperoleh nilai $r_{\text {tabel }} 0,361$. Sehingga $0,939>0,361$ maka instrument variabel $\mathrm{Y}$ dinyatakan reliabel.

\section{Uji Normalitas}

Uji normalitas untuk menguji variabel pengganggu atau residual memiliki distribusi normal dalam model regresi dengan menggunakan uji statistik One sample Kolmogorov-Smirnov dengan taraf signifikan 0,05. Data dinyatakan berdistribusi normal jika signifikansi lebih besar dari 0,05 atau signifikansi $>0,05$.

\section{Uji Normalitas Gaya kepemimpinan $\left(\mathrm{X}_{1}\right)$}

Uji normalitas gaya kepemimpinan sebesar 0,557 dan nilai signifikansi atau Asymp Sig sebesar 0,882 dan nilai signifikansi atau Asymp. Sig sebesar 0,418. Apabila dibandingkan dengan taraf signifikansi 5\% diperoleh sig. $\mathrm{X}_{1}>0,05$ atau $0,418>0,05$ maka Ho diterima Disimpulkan distribusi data gaya kepemimpinan normal.

\section{Uji Normalitas Loyalitas karyawan $\left(\mathbf{X}_{2}\right)$}

Uji normalitas Loyalitas karyawan sebesar 0,894 dan nilai signifikansi atau Asymp. Sig sebesar 0,668. Apabila dibandingkan dengan taraf signifikansi 5\% diperoleh sig. $X_{1}>0,05$ atau 0,894 >0,05 maka Ho diterima. Disimpulkan distribusi data loyalitas karyawan normal.

\section{Uji Normalitas Kinerja karyawan (Y)}

Uji normalitas kinerja karyawan sebesar 0,746 dan nilai signifikansi atau Asymp.Sig sebesar 0,682. Apabila dibandingkan dengan taraf signifikansi 5\% diperoleh sig. $\mathrm{Y}>0,05$ atau 0,746 >0,05 maka Ho diterima. Disimpulkan distribusi data kinerja karyawan normal.

\section{Hasil Penelitian Kuantitatif}

\section{Hasil Uji Hipotesis}

Hasil uji hipotesis menggunakan koefisien regresi parsial diukur melalui $\mathrm{Uji} \mathrm{t}$ yang hasil uji koefisien regresi parsial dapat dijabarkan sebagai berikut: (1) Uji-t pengaruh gaya kepemimpinan terhadap kinerja karyawan RSI Hidayatullah Yogyakarta, bahwa Persamaan regresi mengenai pengaruh gaya kepemimpinan terhadap kinerja karyawan RSI Hidayatullah Yogyakarta bahwa Y = $14.378+0,221 \mathrm{X}_{1}$. Baik skor konstan maupun beta signifikan, skor probabilitas (Sig.) 0.000 yang berarti lebih kecil dibandingkan dengan taraf signifikan 0,05. Uji persamaan tersebut menunjukkan terdapat pengaruh gaya kepemimpinan terhadap kinerja 
karyawan RSI Hidayatullah Yogyakarta. (2) Uji-t Variabel loyalitas karyawan dengan kinerja karyawan RSI Hidayatullah Yogyakarta. Persamaan regresi pengaruh loyalitas karyawan dengan kinerja karyawan RSI Hidayatullah Yogyakarta bahwa $\mathrm{Y}=14 . .378+$ $0,601 \mathrm{X}_{2}$. Baik skor konstan maupun beta signifikan, yakni diperoleh skor probabilitas (Sig.) 0.000 yang berarti lebih kecil dibandingkan dengan taraf signifikan 0,05. Uji persamaan tersebut menunjukkan terdapat pengaruh loyalitas karyawan dengan kinerja karyawan RSI Hidayatullah Yogyakarta.

\section{Hasil Uji Koefisien Regresi Serentak (Uji F)}

Hasil perhitungan ANOVA tersebut diperoleh informasi tentang hasil perhitungan $\mathrm{F}$ sebesar 33.301 dan probabilitas (Signifikansi) 0.000 berarti lebih kecil dibandingkan dengan taraf signifikansi 0,05, sehingga dapat diambil keputusan bahwa Ho ditolak. Ini karena Sig $0.000<0,05$. Sehingga dapat disimpulkan bahwa gaya kepemimpinan dan loyalitas karyawan berpengaruh terhadap kinerja karyawan RSI Hidayatullah Yogyakarta.

\section{Hasil Uji Koefisien Determinasi}

Hasil perhitungan korelasi ditunjukan hasil $\mathrm{R}^{2}$ sebesar 0,572. Hal ini berarti pengaruh gaya kepemimpinan dan loyalitas karyawan terhadap Kinerja karyawan RSI Hidayatullah Yogyakarta adalah sebesar 57,20\%. Sedang sisanya sebesar 42,80\% dipengaruhi oleh variabel lain yang tidak diteliti seperti semangat kerja, pengalaman kerja dan kompensasi yang tidak tercakup dalam penelitian ini.

Hasil perhitungan korelasi ditunjukan hasil $\mathrm{R}$ Squaresebesar 0,327. Hal ini berarti pengaruh gaya kepemimpinan dan loyalitas karyawan terhadap Kinerja karyawan RSI Hidayatullah Yogyakarta adalah sebesar 32,70\%. Sedang sisanya sebesar 67,30\% dipengaruhi oleh variabel lain yang tidak diteliti seperti semangat kerja, pengalaman kerja dan kompensasi yang tidak tercakup dalam penelitian ini.

Hasil perhitungan korelasi ditunjukan hasil Adjusted R Squaresebesar 0,317. Hal ini berarti pengaruh gaya kepemimpinan dan loyalitas karyawan terhadap Kinerja karyawan RSI Hidayatullah Yogyakarta adalah sebesar $32,70 \%$. Sedang sisanya sebesar $67,30 \%$ dipengaruhi oleh variabel lain yang tidak diteliti seperti semangat kerja, pengalaman kerja dan kompensasi yang tidak tercakup dalam penelitian ini.

\section{Garis Regresi Linier}

Diperoleh persamaan regresi linear multipel sebagai berikut :

$$
\hat{\mathrm{Y}}=14.378+0,221 \mathrm{X} 1+0,601 \mathrm{X} 2 \text {. Konstanta }
$$

sebesar 14.378 secara sistematis menyatakan bahwa jika nilai variabel bebas $\mathrm{X}_{1}$ dan $\mathrm{X}_{2}$ sama dengan nol, maka nilai $\mathrm{Y}$ adalah 14.378. Koefisien regresi $\mathrm{X}_{1}=$ 0,221 menyatakan bahwa setiap terjadi peningkatan atau penurunan satu unit gaya kepemimpinan maka akan meningkatkan atau menurunkan kinerja karyawan RSI Hidayatullah Yogyakarta sebesar 0,221. Koefisien regresi Loyalitas karyawan $\mathrm{X}_{2}=0,601$ menyatakan bahwa setiap terjadi peningkatan atau penurunan satu unit motivasi maka akan meningkatkan atau menurunkan kinerja karyawan RSI Hidayatullah Yogyakarta sebesar 0,601.

\section{Pembahasan}

\section{Pengaruh Gaya kepemimpinan dengan Kinerja karyawan}

Hasil uji regresi diperoleh baik skor konstan maupun beta masing-masing signifikan, yakni diperoleh uji t terbuktisecara univariat, sesuai dengan tabel uji t yang dibuat di depan perhitungan diperoleh variable gaya kepemimpinan thitung sebesar 2,534 dengan signifikansi sebesar 0,012. Bila thitung dikonsultasikan dengan ttabel maka diperoleh 2,534> 1,980, dan bila dikonsultasikan dengan taraf signifikan $5 \%$ diperoleh $0,012<0,05$, maka ada pengaruh yang positif dan signifikan gaya kepemimpinan dengan Kinerja karyawan di Rumah Sakit Islam Hidayatullah Yogyakarta.

Sesuai teori Hal ini sesuai teori Ralph dan Ronald $(2001)^{7}$ corak atau gaya kepemipinan yang benar-benar disertai dengan gaya kepemimpinan (leadership) seorang manajer akan sangat berpengaruh terhadap efektifitas seorang pemimpin.

Responden memiliki persepsi bahwa Responden memiliki persepsi bahwa setiap karyawan dengan semua jabatan dan pekerjaan selalu dituntut untuk memberikan output yang dapat menguntungkan bagi 
perusahaan. Sehingga kinerja karyawan juga bergantung pada kecermatan dan efisiensi perilaku kerja masing-masing karyawan. Faktor yang mempengaruhi kinerja seseorang adalah kemampuan, dimana kemampuan (ability) karyawan terdiri dari kemampuan potensi (IQ) dan kemampuan reality (knowledge dan skill) artinya pegawai yang memiliki ketrampilan atas pekerjaannya, maka pegawai itu akan lebih mudah mencapai kinerja yang diharapkan (Rival, Veithzal. 2009) ${ }^{8}$.

\section{Pengaruh Loyalitas karyawan dengan Kinerja karyawan}

Berdasarkan hasil uji regresi diperoleh baik skor konstan maupun beta masing-masing signifikan, yakni diperoleh variable gaya kepemimpinan thitung sebesar 7,031 dengan signifikansi sebesar 0,000. Bila thitung dikonsultasikan dengan ttabel maka diperoleh 7,031 > 1,980, dan bila dikonsultasikan dengan taraf signifikan $5 \%$ diperoleh $0,000<0,05$, maka ada pengaruh yang positif dan signifikan loyalitas karyawan dengan Kinerja karyawan Rumah Sakit Islam Hidayatullah Yogyakarta.

Sesuai teori Wasfi Alrawabdeh, $2014^{9}$ melakukan penelitian berjudul How Employees' Loyalty Programs Impact Organizational Performance within Jordanian Banks, menyimpulkan bahwa Loyalitas para karyawan bukan hanya sekedar kesetiaan fisik atau keberadaaannya di dalam organisasi, namun termasuk pikiran, perhatian, gagasan, serta dedikasinya tercurah sepenuhnya kepada organisasi.

Disimpulkan bahwa loyalitas karyawan sebagai variable penelitian yang menurut Ghiselli \& Browm (dalam Kadarwati, 2003) ${ }^{10}$ yang meliputi : Aktifitas fisik, psikis dan sosial berupa sikap mentaati peraturan yang ditentukan, Sikap dan ketaatan berdasar kesadaran dan tanggung jawab, kemampuan untuk mengidentifikasi personal sesuai keahliannya, dan memiliki pengabdian yang kuat.

\section{Pengaruh Gaya kepemimpinan dan Loyalitas karyawan dengan Kinerja karyawan.}

Penerapan gaya kepemimpinan dan loyalitas karyawan harus selalu di evaluasi dan di monitor secara terus menerus dan berkesinambungan, kemudian diadakan perbaikan dan modifikasi sesuai dengan hasil evaluasi dan monitoring serta tujuan yang telah ditetapkan bersama manajer rumah sakit. Loyalitas karyawan umumnya berupa kesediaan karyawan dalam menjalankan tugas pokok dan tugas lainnya untuk pelayanan (Mathis, Robert and Jackson, Jhon H. 2006) ${ }^{11}$.

Hal di atas sesuai perhitungan koefisien regresi serentak Fhitung sebesar 33,301 dengan signifikansi sebesar 0,000. Bila Fhitung dikonsultasikan dengan Ftabel maka diperoleh 33,301 > 8,56, dan bila dikonsultasikan dengan taraf signifikan 5\% diperoleh $0,000<0,05$, maka Ho ditolak. Jadi disimpulkan bahwa ada pengaruh yang signifikan antara gaya kepemimpinan dan loyalitas karyawan secara bersamasama dengan kinerja karyawan.

\section{SIMPULAN}

Berdasar hasil uji regresi terdapat pengaruh yang positif dan significant gaya kepemimpinan terhadap kinerja karyawan Rumah Sakit Islam Hidayatullah Yogyakarta. Berdasar hasil uji regresi terdapat pengaruh yang positif dan signifikan loyalitas karyawan terhadap kinerja karyawan Rumah Sakit Islam Hidayatullah Yogyakarta. Berdasar uji korelasi diperoleh hasil bahwa variabel independen (gaya kepemimpinan dan loyalitas karyawan) berpengaruh positif dan signifikan terhadap kinerja karyawan Rumah Sakit Islam Hidayatullah Yogyakarta.

\section{DAFTAR PUSTAKA}

1. Mathis, Robert and Jackson, Jhon H. 2006. Human Resource Management. Salemba Empat ; Jakarta

2. Selvilla, Finley, D.A., Crawford, A. ,Rivera D. Jr. 1993. An exploratory study identifying soft skill competencies in entry-level managers, Tourism and Hospitality Research, 9 (4): 353361

3. Aini, Qurratul 2004. Hubungan Antara Gaya Kepemimpinan Dan Komitmen Karyawan Terhadap Kepuasan Kerja Di RSU PKU Muhammadiyah Yogyakarta, Tesis. UGM.

4. Saputra, Rizal. 2010. Pengaruh Gaya Kepemimpinan, Iklim Organisasi, dan Motivasidan Kinerja Karyawan di Riau Pos 
Group Divisi Regional Batam. Batam. Program Pasca Sarjana Ilmu Magister Sains Universitas

5. Azwar, Saifudin. 2009. Reliabilitas dan Validitas. Pustaka Pelajar : Yogyakarta

6. Arikunto Suharsini 2006. Prosedur Penelitian : Suatu Pendekatan Alternatif, Bhineka Cipta : Jakarta

7. Ralph E.Lawler. and Ronald L. Gardon, 2001. Production and The Quality of work Life National Productivity, Review, Winter.

8. Rival, Veithzal. 2009. Kepemimpinan dan Perilaku Organsasi. ed. 2-6 Jakarta Rajawali Pers

9. Wasfi Alrawabdeh, 2011, How employees loyality program simpanct organizational performance within jordanian - banks, Faculty of Economics and Management Science, Hashemite University, Zarqa, Jordan Correspondence:

10. Kadarwati. 2003. Organisasi dan Manajemen, Perilaku, Struktur, dan Proses, edisi Ke-empat, Penerbit Erlangga, Jakarta.

11. Mathis, Robert and Jackson, Jhon H. 2006. Human Resource Management. Salemba Empat ; Jakarta 